\title{
About Engineering-Geonomic Research in the Zeravshan River Pool (Southern Tien Shan) in Connection with Climate Oscillations
}

\author{
Alikhon Akhmadovich Karimov', Narima Kazhenovna Ospanova ${ }^{2}$ \\ ${ }^{1}$ Tajik National University, Dushanbe, Tajikistan \\ ${ }^{2}$ Institute of Geology, Earthquake Engineering and Seismology of the National Academy of Sciences of Tajikistan, \\ Dushanbe, Tajikistan \\ Email: alikhon@bk.ru,ospanova2005@mail.ru
}

How to cite this paper: Karimov, A. A., \& Ospanova, N. K. (2020). About Engineering-Geonomic Research in the Zeravshan River Pool (Southern Tien Shan) in Connection with Climate Oscillations. Journal of Geoscience and Environment Protection, $8,387-394$.

https://doi.org/10.4236/gep.2020.85024

Received: May 7, 2020

Accepted: May 28, 2020

Published: May 31, 2020

\begin{abstract}
Climatic anomalies not only attract the attention of specialists in climatology and meteorology, but also stimulate geological research, because climatic changes activate many geological processes: mudflow and landslide formation, erosion, weathering, etc. An increase in the activity of geological processes was clearly manifested in Tajikistan, $93 \%$ of which is occupied by mountain structures. As a result, this found expression in conducting new for that territory engineering-geonomic studies. Both the region as a whole and its individual parts can serve as models in the study of natural processes due to the diversity of landscape-climatic belts and zones. The report contains brief data on engineering-geonomic studies conducted in the Zeravshan river basin in connection with the intensification of mudflow processes.
\end{abstract}

\section{Keywords}

Climate Change, Mudflow Formation, Engineering-Geonomic Studies, Southern Tien Shan, Tajikistan, Zeravshan River Basin

\section{Introduction}

Scientists wrote that the Earth entered an era of unstable weather back in the 70s of the last century (Svatkov, 1979). This means that weather forecasts based on statistically averaged data for a certain period of time (10, 100 or more years) become inaccurate with respect to the present. In addition, many processes are on an increasing line. This is clearly seen in the graph of temperature changes over the past almost 100 years for the territory of the Republic of Tajikistan (Figure 1). 


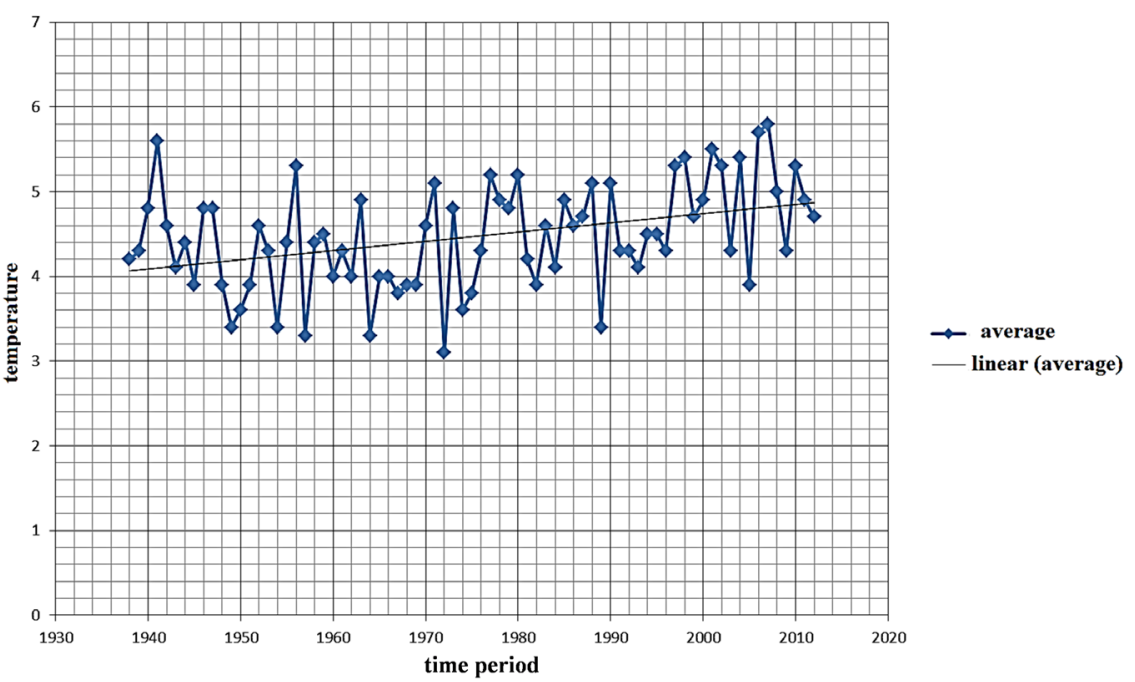

Figure 1. Temperature change for the territory of Tajikistan for the period 1938-2012 (according to the agency for hydrometeorology of the committee for environmental protection under the government of the republic of Tajikistan).

An increase in temperature led to increase in the melting of glaciers, and caused an intensification of the processes of mudflow and landslide formation. It is estimated, for example, that the increase in precipitation in the mountains by $10 \%$ can double the amount of sediment entering the river (Davlatov, 2017). In some years, the amount of precipitation exceeded the norm by twice or more, while in other years the deficiency of humidity provoked aridness, that is, the amount of precipitation and, consequently, the formation of snow cover is variable (Figure 2).

The deep interest in studying the natural resources of this unique region is also due to the fact that Tajikistan takes first place in resources of fresh water among the countries of Central Asia and eighth in the world in hydropower reserves. The large number of water arteries and high sides of mountain valleys are factors that favor the construction of hydropower plants. But melting glaciers will inevitably lead to water shortages, increased desertification, and loss of productivity. At the same time, neighboring countries may suffer, the water supply of which depends on Tajikistan.

The variety of natural and climatic conditions allows us to consider both the region as a whole and its individual parts as model when studying various natural processes. 93\% of Tajikistan is mountainous. The range of heights is from 300 to 7495 meters. Different landscape and climatic zones and belts converge here, from subtropical to nival. Strong rugged terrain, branched hydrographic network, and steepness of slopes, slight development of soil cover on inclined and rocky surfaces, which leads to poor development of vegetation and, consequently, poor cementation of the soil, the presence of a large number of glaciers and lakes, many of which may be a threat in case of floods or earthquakes, as well as other factors create high danger of the formation of natural geo-risks of a very different types. It is believed that up to 500 events of a catastrophic nature 


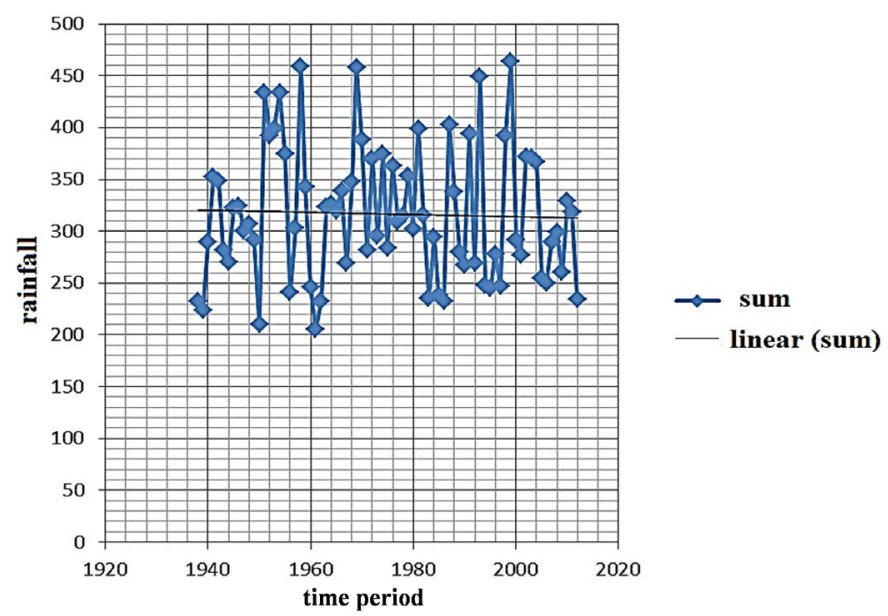

Figure 2. Change in precipitation for the territory of Tajikistan for the period 1938-2012 (source see Figure 1).

occur annually in Tajikistan (Davlatov, 2017). All of the above is the reason that in the last decade, the engineering-geonomic studies direction new for this territory has been actively developed (Usupaev, Moldobaev, Usubaliev, Abdybachaev, Meleshko, \& Abdrakhmanova, 2009; Valiev, 2015, 2018; Karimov, 2018; Karimov, Nabiev, \& Nazarov, 2015; Karimov, Andamov, Aslamov, \& Nazarov, 2019; Karimov \& Valiev, 2019).

\section{Methodological Foundations of Engineering-Geonomic Research}

The term "geonomy" was introduced by V. V. Belousov (1963) to denote a new-complex-way of research in earth sciences. When studying endogenous processes, geonomy should combine geological, geophysical, and geochemical research methods. It is important that geological phenomena receive not only a qualitative, but also a quantitative assessment. Sharing methods can produce results that cannot be achieved using one of them. Together with the engineering-geological approach, the method is considered as engineering-geonomic.

In the future, geonomy was elevated to the rank of the holistic concept of the Earth's self-development, expanding its boundaries not only to exogenous processes, including tectonic and catastrophic phenomena, but also adding biological, environmental and astronomical factors here (Krut', 1978; Usupaev, 1986; Urazaev, 2003). Sh. E. Usupaev (2016: p. 10) gives the following definition of engineering geonomy: "Engineering geonomy is a science that studies the legitimacy of the geoid's genesis, a multicomponent, dynamically active celestial body, transformed by changes in the space environment and the circulation of poly-grounds, for assessing, typing, forecasting deposits and geo-risks, ensuring human noospheric safety". From the standpoint of such an integrated approach, any of the geological objects (up to the Earth), to which engineering-geonomic research is directed, receives a multifaceted characteristic. When carrying out engineering-geonomic studies, the study area is first typified according to certain 
criteria, and objects are ranked from large to smaller. Such units, typified by a certain attribute, are called geomons, for example, the geonom of glaciation, the geonom of valley, the geonom of dissection, the geonom of loess, etc. A map of the area, region or the larger geological and geographical unit, up to the geoid (depending on the goal) is compiled or taken as a basis. The contours of the geonoms are plotted on the map, and if necessary, their altitudinal and latitudinal tracking is performed. The complex of heterogeneous geonoms, tied to a specific territory, allows classifying geo-risks, highlighting graphic areas of greatest vulnerability, and also revealing structural subordination of various components of the environment.

\section{Brief Description of the Zeravshan River Basin}

The Zeravshan river basin, which is one of the most mudflow hazardous areas of the country, can serve as a model for studying climate fluctuations and the consequences it causes. It is located at altitudes from 1000 to 6000 meters and covers an area of more than 12,000 square kilometers. This is slightly less than the area of the Bahamas, but more than the area of such states as the Qatar, Gambia, Jamaica, Lebanon or Cyprus. The Zeravshan, Turkestan and Alai ranges of the Tien Shan converge here into a powerful mountain junction. The width of the valley (bottom) ranges from a few meters to 6.8 kilometers. The formation of a large number of mudflows is facilitated by the wide distribution of easily eroded loose rocks, the strong ruggedness of the relief and the steepness of the slopes, and the presence of a large number of glaciers (up to 4000 glaciers of different sizes), an extensive hydrographic network and the continental climate characterized by sharp daily and seasonal temperature fluctuations. Mudflows of all types are formed, from cohesive (mud and mudstone) to incoherent (alluvial). The situation is aggravated by the fact that Tajikistan is located in a seismically dangerous zone, most of which falls into an 8 - 9-magnitude seismicity zone-almost $85 \%$ (Babaev, Koshlakov, \& Mirzoev, 1978). If earlier from 1000 to 3000 earthquakes were recorded per year (Bibarsova, Mirzoev, Mikhailova, Sviridov, \& Timerkaev, 1986; Sanginov \& Karimov, 2014), then now, due to the increase in the seismicity process as a whole and the commissioning of sensitive equipment (digital seismic stations) capable of detecting earthquakes of low scores, the number of recorded earthquakes exceeds 20,000 per year (oral communication from the academician Negmatullaev S.Kh.). It is planned to build a cascade of dam and derivational hydroelectric power stations on the river, designed for many years of regulation of runoff for the purpose of its energy and water management, and studying the geoecological situation of the region is an important task (Karimov \& Valiev, 2016).

In connection with abnormal weather conditions and intensification of mudflow-landslide processes that caused significant economic damage to the country's economy, one of the authors was tasked with assessing the state of the Zeravshan river basin following traces of mudflows in order to obtain high-quality data on the formation and movement of mudflows, the dynamics of their impact 
on barriers and anti-mudflow constructions and clarification of the degree of mudflow hazard.

\section{Some Characteristic Features of Mudflow Manifestations in the Highlands}

The authors compiled a table in which the relationship of the scale and periodicity of the mudflow manifestation is displayed depending on the underlying causes (Table 1). The main factor in the formation of mudflows of zonal manifestation is climatic conditions (precipitation). Mudflows happen locally, but their descent occurs systematically. The paths of movement are relatively constant. The main factor in the formation of mudflows on a regional scale is geological processes. The gathering occurs sporadically, and the paths of movement are inconsistent. Mudflows of anthropogenic genesis are associated with human economic activity that upsets the natural balance and thereby creates the conditions for the development of mudflows where they might not have been. They occur occasionally in places of greatest load on the mountain landscape. In this case, new mudflow basins may form. When compiling the table, the authors took into account that it can be applied to the entire territory of the republic, which is confirmed by the examples below.

If, under climatic influences, the leading role in formation of mudflow belongs to water (long rains, heavy rains, melting of snow and ice), then in the case of geological factors, the leading role belongs to gravitational processes that generate landslips, collapses, and taluses. They serve as an additional supplier of mudflow material. Often the cause of landslides and collapses are earthquakes. During the Hait earthquake of 1949 , the landslip with a capacity of 70 meters covered the district center of Hait together with its inhabitants and blocked the river. The accumulated water broke through the dam and formed the mudflow. In the Yasman River Valley, many villages were buried under mud-stone avalanches (Ischuk, Schwartz, Ischuk, \& Ilyasova, 2013). In total, more than 150 villages were damaged or destroyed, of which more than 30 were buried under landslides. More than 20,000 people died (Sanginov \& Karimov, 2014). In the Late Quaternary basin of the Zeravshan River, the Tangisay River valley (the left inflow of the Rivat River) was blocked by the landslide ( $1-1.5$ million cubic

Table 1. Scale and frequency of mudflow manifestations in the Zeravshan river basin, depending on the causes.

\begin{tabular}{|c|c|c|}
\hline Scale of manifestation & $\begin{array}{l}\text { Frequency of } \\
\text { manifestation }\end{array}$ & $\begin{array}{l}\text { Causes of } \\
\text { occurrence }\end{array}$ \\
\hline Zonal (local) & Systematically & $\begin{array}{l}\text { Climatic conditions } \\
\text { (precipitation) }\end{array}$ \\
\hline Regional & $\begin{array}{c}\text { Periodically } \\
\text { (intermittently) }\end{array}$ & Geological processes \\
\hline $\begin{array}{l}\text { Unpredictable (formation of new mudflow basins, } \\
\text { increased pressure on the mountain landscape) }\end{array}$ & Occasionally & Human Engineering \\
\hline
\end{tabular}


meters in volume) that formed in Ludlow limestones. In the area of the collapse, the elevation reaches 200 - 300 meters. The erosion of the rocks of the collapse contributes to the enrichment of mudflows with clastic material, and the presence of waterfalls on the creek causes a jump-like increase in the velocity of mudflows.

When geological processes are applied, the scale of mudflow manifestations increases because rock collapses can reach thousands and millions tons of weight and because an earthquake covering large areas can provoke not one, but a series of collapses or landslides. In addition, this process can be extended over time: weakened rock masses, if they do not collapse immediately, can experience repeated movements in the future, periodically entering the water.

The formation of mudflows as a result of anthropogenic activity is promoted mainly by deforestation, strengthening the slopes; land clearing for arable land; prolonged wetting of the slopes during irrigation, as a result of which the adhesion forces between the soil layer and underlying rocks are weakened; the construction of hydroelectric power plants, which not only violate isostasis, but also lead to a change in the hydrography of the area, siltation and washing of the coasts, and in case of breaking or washing out of dams, they can provoke the formation of mudflows. For example, in June 1999, rains provoked a series of mudflows in the vast territory of the region, including in the Zeravshan river ba$\sin$. Here $80 \mathrm{~km}$ of roads, 18 hectares of farmland were destroyed, and in other areas the infrastructure was severely damaged and many people died.

With prolonged artificial humidification of the slopes, even insignificant earthquakes can cause soil liquefaction with the formation of landslides and mudflows, as it happened during the Gissar earthquake of 1989, when a giant mud stream of 3.5 kilometers was formed. Researchers point out that all the main areas of Tajikistan cultivated for agriculture are concentrated in areas of development of loessial soils, and the effect of thinning loessial soil is possible in almost the entire territory developed for agriculture (Ischuk, Schwartz, Ischuk, \& Ilyasova, 2013).

\section{Study Results}

The complex of engineering-geonomic studies of the watercourses of the Zeravshan River basin allows revealing the features of changes and transformations of the geological environment under the influence of natural and technogenic loads causing geo-risks. As a result of the study, an engineering-geonomic assessment of the development of mudflows and typification of associated geo-risks was made, the engineering-geonomic models of the laws of lateral and altitudinal distribution of geo-risks in the Zeravshan river basin were constructed, and the area of greatest vulnerability was outlined. A set of measures was also developed to reduce the risk of natural and man-made geo-risks in this area (Karimov \& Olimov, 2019). To reduce the risk of natural geo-risks, a map of the tracking network has been compiled, which will make it possible to organize observations of mudflow processes and the extent of their manifestation. 


\section{Conflicts of Interest}

The authors declare no conflicts of interest regarding the publication of this paper.

\section{References}

Babaev, A. M., Koshlakov, G. V., \& Mirzoev, K. M. (1978). Map of Seismic Zoning of Tajikistan (Explanatory Note). Dushanbe: Donish.

Belousov V. V. (1963). About the Ways of Development of Geological Science. Soviet Geology, 1, 11-28.

Bibarsova, D. G., Mirzoev, K. M., Mikhailova, R. S., Sviridova, L. N., \& Timerkaev, V. S. (1986). Databanks of the Regional Center of ASPA of Central Asia and Kazakhstan and their Use for Solving Seismological and Geophysical Problems. In Earthquake Forecast (pp. 182-204). Dushanbe-Moscow: Donish.

Valiev, Sh. F. (2015). Engineering-Geological Features of the Transformation of the Roof of the Lithosphere of Mountainous Countries (on the Example of Tajikistan). Doctor of Geological-Mineralogical of Sciences. Abstract, Bishkek.

Valiev, Sh. F. (2018). Monitoring Criteria and Signs of the Threat of Natural Geo-Risks in the Turkestan-Alai Region. Proceedings of the Republican Scientific-Theoretical Conference Dedicated to the International Decade of Action "Water for Sustainable Development, 2018-2028”(p. 145). Dushanbe.

Davlatov, A. (2017). Tajikistan and the Problems of Climate Change. Science and Innovation. Natural Science Series. Proceedings of the International Scientific-Practical Conference on the Theme "Climate Change and Hydro Resources of Central Asia" (pp. 84-87). Dushanbe.

Ischuk, A. R., Schwartz, A. V., Ischuk, N. R., \& Ilyasova, Z. G. (2013). Seismic Hazard and the Prediction of Landslides during Earthquakes in the Mountainous Regions of Tajikistan. Dushanbe: JSC Chopkhonai Donish.

Karimov, A. A. (2018). Engineering-Geonomic Assessment and Typification of Foci of Solid Runoff of Mudflows of the Zeravshan River Basin. Science, New Technologies and Innovation, 2, 77-81. (Bishkek)

Karimov, A. A., Nabiev, N. F., \& Nazarov, J. O. (2015). On the Gravitational Processes of the Zeravshan River Basin. Science, New Technologies and Innovations of Kyrgyzstan, 11, 11-16.

Karimov, A. A., \& Valiev, Sh. F. (2016). Potential Geo-Risks as a Consequence of the Construction of the Zeravshan Cascade of Hydroelectric Power Stations and Their Expected Scale. Science, New Technologies and Innovations of Kyrgyzstan, 7, 32-35.

Karimov, A. A., Andamov, R. Sh., Aslamov, B. R., \& Nazarov, J. O. (2019). Geotechnical Engineering Assessment and Typification of Geo-Risks Associated with Exodynamic Processes in the Zeravshan River Basin. Science and Innovation (Series of Geological and Technical Sciences), 1, 151-157.

Karimov, A. A., \& Valiev, Sh. F. (2019). Monitoring of Natural Geo-Risks in the Zeravshan River Basin. Science and Innovation (Series of Geological and Technical Sciences), 2, 52-58.

Karimov, A. A., \& Olimov, K. K. (2019). Anti-Mudflow Constructions of Some Sections of the Zeravshan River Basin and Georisk Prevention Measures. Kishovarz, 2, 147-149.

Krut', I. V. (1978). Introduction to the General Theory of the Earth. Levels of Organization of Geosystems. Moskow: Thought. 
Sanginov, A. M., \& Karimov, R. Sh. (2014). Earthquake-Resistant Buildings with Brick and Stone Walls. Proceedings of the Scientific Conference "Geology and Issues of Seismicity in the Territory of Tajikistan" Dedicated to the 80th Anniversary of Academician of the Academy of Sciences of the Republic of Tatarstan, Doctor of Geological and Mineralogical Sciences, Dzhalilov Manzur Rakhimovich (pp. 199-214). (Dushanbe)

Svatkov, N. M. (1979). The Earth's Mirror of the Sun (Essay on the Paleotemperature of the Earth). Moscow: Mysl.

Urazaev, K. A. (2003). Earth Rotation and Geological Processes. Ufa: RIO of Bash SU.

Usupaev, Sh. E. (1986). Engineering Geonomy Is a New Way of Development of Geology and Engineering Geologists. Proceedings of the VIII Inter-Republican Scientific Conference of Young Scientists (pp. 143-147). (Frunze)

Usupaev, Sh. E., Moldobaev, B. D., Usubaliev, R. A., Abdybachaev, U. A., Meleshko, A. V., \& Abdrakhmanova, G. A. (2009). Engineering-Geonomic Risk Assessment Models for Glacier Degradation and Climate Change Using the Example of the Mountainous Countries of Kyrgyzstan and Tajikistan (Comparatively Catastrophic Aspects). Proceedings of the Scientific Conference "Prospects for the Use of Water and Energy Resources of Tajikistan in the Context of Climate Change”(pp. 55-59). (Dushanbe)

Usupaev, Sh. E. (2016). IGN-Models of the Genesis of the Geoid and the Prediction of Geo-Risks of the Earth. News of the NAS of the Kyrgyz Republic, 4, 9-17. 